\title{
Environmental education for the sustainable development of suburban communities in Ho Chi Minh City
}

\author{
Hoi Huynh Tan ${ }^{1, *}$ \\ ${ }^{1}$ FPT University, Vietnam
}

\begin{abstract}
Rapid urbanization contributes to a widening gap between the rich and the poor, which also increases the pressure on natural resources and the environment. Many industrial establishments emit uncontrollable hazardous substances and a lot of the waste belongs to the municipalities. Some of municipal waste is discharged into rivers and canals. In Ho Chi Minh City, the issue is not only a pressing issue of the city government but also affects the health of the people and the urban beauty. And as a result, it is currently the most polluting source for the city's canals. This study focuses on the assessment of environmental issues, environmental awareness and its impact on the livelihoods of suburban residents. By carrying out a survey, the research results show that many environmental problems have appeared quite serious and complicated developments. The article proposes some environmental education solutions for sustainable development with the people-focused principle in order to promote the responsibility of the people.
\end{abstract}

\section{Introduction}

Since the early 1990 s, solid waste management (Solid Waste Management) has always been a pressing problem of the city but has not been resolved due to the lack of investment capital, equipment, technical knowledge, and awareness of the people on the magnitude of this issue [1]. Household waste is usually kept at home and collected in plastic bags or trash baskets for 24 hours or 2-3 days. However, the capacity of the current waste collection and treatment system to meet the needs of all income neighborhoods in the city also makes it difficult to collect waste, as the This area lacks appropriate equipment and people do not want to pay extra for the collection.

Every year the city generates $1,200,000-1,400,000$ tons of solid waste (about 3,500 tons per day) with an average rate of $20 \%$ per year. The landfills currently do not have the capacity to receive the entire amount of waste and at the dumping sites the garbage is classified and not followed any sanitation procedures. The former landfill in Tan Thanh (Hoc Mon) is close to the periurban area, has now moved to the Northwest of $\mathrm{Cu}$ Chi (rural area) and is planning to develop more landfills in Long An (in the urban area HCM expansion). The overgrowth weighs heavily on the existing infrastructure and services. Once the air, water and soil in the cities are seriously polluted and green spaces disappear, people cannot survive in a healthy and productive manner for long. Further a bad environment will affect the value of fixed assets and investors will leave [2].

In recent years, when socio-economic conditions have developed rapidly, many environmental problems also appear more and more and become more serious and have a great impact on socio-economic development. and human life, affecting the sustainable development of the community [3]. Therefore, environmental protection is currently considered an important issue and is posed as an indispensable requirement for the sustainable development of ethnic minorities [2]. However, many programs for environmental protection for suburban communities are often ineffective mainly due to inappropriate approaches, implementation methods or content. Therefore, this study focuses on the assessment of environmental issues, environmental awareness and suggests an appropriate approach in environmental education for the sustainable development of the Mong community in particular and ethnic minorities in general, for example in Simacai district, Lao Cai province.

\section{Research method}

The study is conducted in the period of 2020 in Hoc Mon district. The study used the participatory rapid assessment method, open questionnaires combined with direct interviews with people living in the area. People's participation during the survey. In it, from identifying environmental problems, discussing causes and consequences, implementing and managing and evaluating models. In general, the semi-structured questionnaire is divided into three main groups: The first group of problems related to economic development and natural resource use, the second group related to human perception [4] people about environment and the third group of issues related to environmental issues and environmental education. Due to the high similarity in lifestyle and living habits of suburban residents, the

*Corresponding author: hthcolin@gmail.com 
study randomly selected 50 residents for interviews. Base on the actual research results, it is important to develop an approach to environmental education for the sustainable development of ethnic minorities for the community [5].

\section{Results and discussion}

\subsection{Some characteristics of people living in suburbs of Ho Chi Minh City}

According to custom and tradition, people are solely responsible for solving common problems of the community. People voluntarily abide by the general rules, especially in the fields of agricultural production, livestock husbandry, forest protection, social order maintenance and mutual assistance [4].

For many centuries, people still lived in harmony with the surrounding nature with their own experiences such as forest protection conventions, farming experience, culture and beliefs, organization and activities of the community.

These experiences are gradually formed into indigenous knowledge and passed down in each family and community, from generation to generation mainly by word of mouth [6]. Therefore, indigenous knowledge also has a lot to change over time and in each community. In general, indigenous knowledge is valuable life and production experience for the ethnic people to live in harmony with nature. However, indigenous knowledge is often limited to a small range of communities and only suitable for natural, cultural and socio-economic conditions of certain localities. In particular, in the current period of socio-economic development, the natural ecosystem is seriously degraded, many indigenous knowledge is no longer suitable in the newly emerging conditions. Therefore, it is necessary to research and select knowledge suitable for current conditions to ensure sustainable development in the future [7].

\subsection{Rural environmental issues}

\subsubsection{Agricultural production development and natural resource use}

To develop socio-economic, people focus on two forms of agricultural production development (cultivation and animal husbandry) towards goods to quickly eradicate poverty. However, the increasing number of the population (up to the year 2020) is also a problem of concern (Table 1). Hoc Mon district although has a limited area but its population density is rather high.

Table 1. Area, communes and population of suburban districts of Ho Chi Minh City

\begin{tabular}{|l|c|c|c|}
\hline \multicolumn{1}{|c|}{ District } & Number of ccommune & Area (km $\mathbf{( k}^{\mathbf{2}}$ & Population \\
\hline Hoc Mon & 12 & 109.17 & 542.000 \\
\hline Can Gio & 7 & 704.45 & 71.000 \\
\hline Cu Chi & 21 & 434.88 & 462.000 \\
\hline Nha Be & 7 & 100.43 & 206.000 \\
\hline Binh Chanh & 16 & 252.56 & 706.000 \\
\hline
\end{tabular}

Survey results in 50 households showed that, in daily livelihoods, some people consider natural resources available and use them in an unsustainable manner so the extraction process is often not associated with the regeneration. The survey results show that up to $28 \%$ of the respondents participated in fishing in fields and rivers. Many (42\%) of the respondents use pesticide for their harvest (Table 2).

Table 2. Resource exploitation and use of plant protection drugs in rural areas

\begin{tabular}{|l|l|c|c|}
\hline \multicolumn{1}{|c|}{ Category } & \multicolumn{1}{|c|}{ Activities } & $\begin{array}{c}\text { Number of } \\
\text { households (50) }\end{array}$ & Ratio (\%) \\
\hline \multirow{2}{*}{ Wild fishing } & Engaged & 14 & 28 \\
\cline { 2 - 4 } & Not engaged & 36 & 45 \\
\hline \multirow{2}{*}{ Use of plant protection drugs } & Use & 21 & 52 \\
\cline { 2 - 4 } & Do not use & 29 & 0 \\
\hline
\end{tabular}

\subsubsection{Livestock management and domestic waste}

In recent years, the socio-economic conditions in Hoc Mon district have developed significantly, at the same time, the domestic waste is generated significantly, causing environmental pollution in rural mountainous areas. Especially in the surrounding public places such as markets, village streets, public play areas and so on.
The most common way to treat domestic waste is burning (40\%), simple burial in home garden (26\%) and freely freely discharged into the surrounding environment (34\%) (Table 3). In addition, all domestic wastewater is discharged directly into the soil or natural water source without any application of period of treatment, causing environmental pollution (Table 3). 
Table 3. Livestock waste and domestic waste management

\begin{tabular}{|l|l|c|c|}
\hline \multirow{2}{*}{ Categories } & \multicolumn{1}{|c|}{ Management form } & $\begin{array}{c}\text { Number of } \\
\text { households (n=50) }\end{array}$ & $\begin{array}{c}\text { Ratio } \\
\text { (\%) }\end{array}$ \\
\hline \multirow{4}{*}{ Domestic waste management } & & 20 & 40 \\
\hline \multirow{3}{*}{ Toilet } & Burning & 13 & 26 \\
\cline { 2 - 4 } & Buried in the garden & 17 & 34 \\
\cline { 2 - 4 } & Free disposal into the environment & 28 & 56 \\
\hline \multirow{2}{*}{ Handling manure of cattle and poultry } & There are toilets & 18 & 36 \\
\hline \multirow{2}{*}{ Animal management } & There are rudimentary toilets & 16 & 32 \\
\cline { 2 - 4 } & There is no toilet & 13 & 68 \\
\cline { 2 - 4 } & Do not collect feces & 37 & 26 \\
\hline \multirow{2}{*}{ Domestic water source } & Free grazing & 37 & 74 \\
\cline { 2 - 4 } & There is a separate barn & 13 & 64 \\
\hline
\end{tabular}

For livestock management, due to the tradition of free-grazing on a small scale, people have not paid attention to the collection of livestock waste, so it has become a huge source of environmental pollution. The habit of keeping pets on the floor is still quite popular, causing environmental pollution, directly affecting human health. Furthermore, many households have toilets but fail to meet the requirements $(36 \%)$, which is an important cause of many problems of rural sanitation and the source of the pathogens that directly affect the health of citizen.

\subsubsection{Environmental pollution caused by pesticides used in agriculture}

In the past, the people's agricultural production was mainly shifting cultivation according to the traditional farming method. However, in recent years, agriculture has developed in the direction of intensive farming with high economic value crops [8]. In shifting cultivation, instead of cutting and burning for cultivation in the past, people now use herbicides directly to kill weeds. The consequences of overuse of herbicides have a strong impact on the environment, can slow down plant growth and yield, and seriously affect human health. The results showed that $100 \%$ of surveyed households used homestead drugs in agricultural production.Many poisonings in humans and animals and even deaths have been recorded. Recipients are directly related to pesticide use in agriculture or in water contaminated with pesticides [3].

\subsection{Environmental awareness approach to environmental education for the people}

\subsubsection{People's awareness of the environment}

Survey results in local communities show that most of the people do not understand the nature of environmental problems as well as environmental protection [5]. They are also not fully aware of the impact between natural resource exploitation and environmental protection for sustainable community development. Up to $56 \%$ of the people are not aware of what the environmental factors are and only $34 \%$ of the people cared for some basic environmental factors such as land, water after being asked for more. However, many respondents (46\%) said that the environment has an impact on their lives and $74 \%$ said that it is necessary (and very necessary) to protect the environment (Table 4).

Table 4. Environmental perceptions and behaviors of suburban residents

\begin{tabular}{|c|c|c|c|}
\hline Parameter & Awareness level & $\begin{array}{l}\text { Number of households } \\
\qquad(\mathbf{n}=\mathbf{5 0})\end{array}$ & $\begin{array}{l}\text { Ratio } \\
(\%)\end{array}$ \\
\hline \multirow{3}{*}{$\begin{array}{l}\text { The impact of the environment on } \\
\text { life }\end{array}$} & Extremely much & 12 & 24 \\
\hline & A lot & 10 & 20 \\
\hline & Unknown & 28 & 56 \\
\hline \multirow{3}{*}{$\begin{array}{l}\text { The need for environmental } \\
\text { protection }\end{array}$} & Very necessary & 9 & 18 \\
\hline & Necessary & 28 & 56 \\
\hline & Unnecessary & 13 & 26 \\
\hline
\end{tabular}




\subsubsection{Approach to environmental education for the community}

In the current communities, due to the limited economy and infrastructure, the environmental protection has not been given adequate attention by the people. New environmental problems arise more and more. Therefore, environmental education for the Mong is very important to contribute to strengthening environmental protection for the sustainable development of the community [7]. The most difficult problem in education and environmental protection for ethnic minorities is changing habits that are no longer suitable with current conditions. With an outdated lifestyle, often only acquiring knowledge from the outside if it really benefits them. Therefore, environmental education for sustainable development needs to suit the specific conditions of each ethnic community and is considered as a significant determinant leading to changes in environmental behavior of people. people. Environmental education is not only important for research on environmental sustainable education, but also needs to be placed in a specific context and able to meet the requirements of economic development and sustainability of the community [4 ].

Defining goals for environmental education should be specific and clear, should not set too many goals will make environmental education ineffective. The goal of environmental education is to make people aware of and care about the environment and issues related to the environment, to have knowledge, skills, attitudes, initiatives and responsibilities with solving existing problems and preventing environmental problems that arise. Environmental education to promote human sustainable development, social sustainability, economic sustainability and sustainable natural environment [6]. On the other hand, in environmental education, it is also necessary to pay attention to issues of environmental ethics and socio-economic aspects. However, in reality, environmental education often fails to meet requirements due to the constant changes in socio-economic conditions as well as environmental factors [8].

From the actual research results, the work of environmental education for sustainable development of ethnic minority communities must achieve the following three goals: Raising environmental awareness, building protection capacity environment and change everyone's environmental behavior. These goals have a relationship of support and motivation.

Regarding the approach to environmental education for suburban communities, it is necessary to inherit and promote the positive aspects of indigenous knowledge on the use of natural resources, promote cultural and religious traditions, beliefs, of ethnic people. However, they need to have a reasonable selection based on science to suit the conditions of each specific locality [9].

The actual research results in local communities show that environmental education for sustainable development for ethnic minority communities should be based on an approach. The proposed contents should be considered in close relation with the characteristics of the local community.

Accordingly, we need to survey and collect the necessary information; Second, we need to analyze the local natural, socio-economic and environmental conditions [10]. Next, we need to identify the causes and consequences of environmental degradation on the community, the priority issues to be addressed. In addition, we need to design environmental education content and programs for sustainable development. We also need to do environmental education. Finally, we need to evaluate the results of the environmental education program, and adjust the content and implementation methods to be more effective. Contents of environmental education should include main contents such as environmental education to raise awareness and capacity to protect the environment for people in different ways, such as training, visual communication, leaflets, etc. We also need to set up self-governing groups to protect the environment to propagate, organize and maintain local environmental protection activities [11]. Another important factor is the development of specific environmental protection models to address priority local environmental issues.

\section{Conclusion}

Currently, the conditions and living standard of Vietnamese people have improved significantly in general. At the same time, this is also the time when many environmental problems arise, such as degradation of forest resources, degradation of land and water resources, and inappropriate use of plant protection drugs. Rural environmental sanitation issues such as livestock waste, waste and domestic wastewater appear more and more serious, directly threaten the sustainable development of the community. Environmental education is considered an important task to change people's perceptions, capacities and behaviors of the environment. The study has identified environmental issues, issues of environmental awareness among suburban residents, as well as the approach to organizing environmental education for sustainable development of ethnic minorities in Vietnam. Base on the conditions of the people in the suburbs, research has identified priorities and proposed frameworks for the approach to environmental education that combine scientific knowledge with indigenous knowledge, promote community responsibility and the role of the responsible people in the locality. The approach to environmental education for sustainable development should be based on specific conditions of each ethnic community and each locality. We need to clearly identify the specific environmental problems, the causes and consequences of environmental degradation on the community. The environmental education program for sustainable development must be practical and associated with specific benefits to the people and the community in general. 


\section{Limitations of the research}

Hopefully, the paper could be improved much more detailed in near future.

Acknowledgement. The author would like to express warm thanks to the Ho Chi Minh City Open University, Ho Chi Minh City, Vietnam for financial support.

\section{Ethical clearance}

I am ensuring the quality and integrity of our research. The ideas and opinions expressed in this paper are of my effort. By writing this research paper, I surely respect the confidentiality and anonymity of my research respondents since they participated in my work voluntarily.

\section{Conflict of interest}

No conflicts of interest noted in the paper.

\section{Source of funding}

The author would like to send the warn thanks to Ho Chi Minh City Open University, Vietnam for the financial support.

\section{References}

1. Phuttharak, T., \& Dhiravisit, A. Rapid urbanizationits impact on sustainable development: A case Study of Udon Thani, Thailand. Asian Social Science 10, 22 (2014).

2. Le Vo, P. Urbanization and water management in Ho Chi Minh City, Vietnam-issues, challenges and perspectives. GeoJournal, 70, 1 (2007).

3. Dan, P., \& Lan Chi, N. T. Global climate change and solutions for urban sustainability of $\mathrm{Ho} \mathrm{CHi}$ Minh City, Vietnam, (2015).

4. Duc, H. N., \& Truong, T. P. Water resources and environment in and around Ho Chi Minh City, Vietnam. Electronic Green Journal, 1, 19 (2003).

5. Storch, H., \& Schmidt, M. Adaptation Planning Framework to Climate Change for the Urban Environment in Ho Chi Minh City. In EnviroInfo, (2008).

6. Van, T. T. Research on the effect of urban expansion on agricultural land in Ho Chi Minh City by using remote sensing method. VNU Journal of Science: Earth and Environmental Sciences, 24, 2 (2008).

7. Phuttharak, T., \& Dhiravisit, A. Rapid urbanizationits impact on sustainable development: A case Study of Udon Thani, Thailand. Asian Social Science, 10, 22, (2014).

8. Wright-Contreras, L., March, H., \& Schramm, S. Fragmented landscapes of water supply in suburban Hanoi. Habitat International, 61, (2017).

9. Tabucanon, M. Education for Sustainable Development-Challenges for Transformative Education and Research. In Abstracts of the 1st
ICERD-International Conference on Environmental and Rural Development, (2010)

10. Sigrist, M. Groundwater Contamination in Asian Coastal Cities: Case Study of Ho Chi Minh City, Vietnam. In Groundwater Management in Asian Cities. Springer, Tokyo, (2008).

11. DiGregorio, M., Rambo, A. T., \& Yanagisawa, M. Clean, Green and Beautiful: Environment and development under the renovation economy. Postwar Vietnam: Dynamics of a transforming society, (2003). 